\title{
State Legislatures as Institutions
}

Gary F. Moncrief, Boise State University

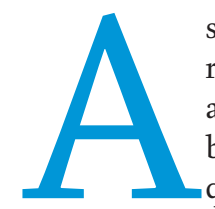

s institutions, legislatures are defined by their rules and structures. Each legislative institution adapts-albeit often slowly and piecemeal-to both external and internal pressures. Consequently, although all American legislatures share some common features, no two are exactly alike, and the behavior of legislators is constrained or facilitated by the details of the legislative design. For researchers, this is one of the great attractions of state legislatures.

Our general theme is that the history of state-legislative scholarship is closely connected to the institutional arrangements of state legislatures. Previously, the literature on state legislatures was reformist in character, expressing a concern for the "institutional lag" of state legislatures and advocating for specific institutional changes. These changes indeed occurred, but not at the same pace in all legislatures. This variation-and the consequences of it-became a defining feature of the next period of state-legislative research, and it remains an important aspect today. Subsequently, the term-limit movement provided a great opportunity in political science to study the effect of an exogenously induced institutional change. Finally, the variety of procedural operations-coupled with the structural differences among state legislatures-spurred an interest today in how institutional rules constrain or encourage behavioral outcomes.

\section{INSTITUTIONAL LAG AND LEGISLATIVE SCHOLARS AS REFORM ADVOCATES}

In 1949, investigative journalist Robert Allen wrote a scathing analysis of the condition of state governments in the United States. His ire was especially aimed at state legislatures, about which he wrote:

\footnotetext{
Without exception, legislatures, as a whole, are a shambles of mediocrity, incompetence, hooliganism and venality.... State legislatures are the most sordid, obstructive, and anti-democratic law-making agencies in the country. (Allen 1949, xxxvi)
}

It might be tempting to dismiss this hyperbolic display as the sensationalism of a muckraking journalist. But even the more reserved academic assessment of legislative scholars sounded a similar (if less dramatic) theme. For example, in 1954, the American Political Science Association's Committee on American Legislatures, headed by Professor Belle Zeller, released its report documenting the historical decline of state legislatures as important policy-making bodies (Zeller 1954).
In 1966, a conference was convened in New York that brought together about 15 leading legislative scholars of the day. Also in attendance were a number of state legislative leaders, civic leaders, and representatives from several major philanthropic foundations. The conference papers, published later that year as State Legislatures in American Politics, were a clear call for institutional reform. It was in the introduction to this book that Heard $(1966,2)$ wrote: "State legislatures may be our most extreme example of institutional lag."

During this period, there was an extraordinary effort to erase this institutional lag. It is important to remember the substantial changes in American society during this period. In 1920, the United States was a country of 106 million people equally divided between urban and rural populations. By 1970, the population had doubled, to 213 million, and almost $75 \%$ of the population was living in urban areas. The country had become more populated and less rural-but state legislatures had not changed much at all.

Led by a coalition of civic organizations, foundations, state-legislative scholars, legal activists, and legislative leaders, there was an organized and concerted campaign to alter state legislatures. One of the organizations most enthusiastic and supportive of state-legislative reform was the National Municipal League (Wiltsee 1966, 37). City leaders, especially those in larger cities, often felt that their state legislatures were unresponsive to urban constituents.

The reform and modernization movement had two main purposes: (1) develop the capacity of legislative institutions, and (2) affect a reapportionment revolution. Reformers recognized that capacity building would be viable only if malapportionment could be eliminated. So, at roughly the same time that the reapportionment revolution was occurring, the legislative-capacity movement was moving ahead. It was a concerted and organized effort that engaged academics, journalists, and others in an attempt to sway public opinion. For example, in April 1965, an article appeared in the National Civic Review entitled, "Hamstrung Legislatures," which illuminated various ills and argued that state legislatures were in need of reform-especially "increased pay," "increased time," and "increased staff" (Miller 1965). The article was reprinted in the May 1965 issue of Reader's Digest-the 1960 s version of retweeting.

Soon thereafter, former North Carolina Governor Terry Sanford $(1967,182)$ published Storm over the States, another call for reform, in which he argued: "We have so much riding on state legislatures that they are going to have to rise to their challenges." By 1971, this movement hit full stride with the publication of The Sometimes Governments: An Evaluation of the Fifty American Legislatures (Burns 1971) and Strengthening 
the States: Essays on Legislative Reform (Herzberg and Rosenthal 1971). This period has been called the "heyday of legislative reform" (Kurtz 2010, 85). The political science literature during this period clearly reflects that reformist tone, describing the current state of state legislatures and unabashedly advocating for institutional change.

\section{VARIATION IN INSTITUTIONAL CAPACITY: THE STUDY OF THE EFFECTS OF REFORM}

During the next decade, many state legislatures indeed built their institutional capacity and changed in significant ways, through what Rosenthal (1998) called "the five S's": space, session, structure, staff, and salary. The concerted effort to persuade the American public of the need to modernize state legislatures paid off. As Squire $(2012,304)$ showed, voters
Using text-analysis programs, these studies found that legislators in poorly staffed legislatures with shorter sessions are decidedly more likely to adopt "model legislation" verbatim from particular interest groups or from other states. Meanwhile, legislators in more professional legislatures are more likely to develop their own legislation or to rewrite model legislation to adapt it to their own conditions (Hertel-Fernandez 2014; Jansa, Hansen, and Gray 2018).

\section{TERM LIMITS AND THE "NATURAL EXPERIMENT" IN STATE-LEGISLATIVE RESEARCH}

The imposition of state-legislative term limits in the $1990 \mathrm{~s}$ was the most significant institutional change in American legislatures since the capacity-building and reform efforts of the 1960 s and 1970 (Kurtz, Cain, and Niemi 2007, 1). In part

\section{Led by a coalition of civic organizations, foundations, state-legislative scholars, legal activists, and legislative leaders, there was an organized and concerted campaign to alter state legislatures.}

in more than half the states approved one or more capacitybuilding components (e.g., increases in legislative salary, session time, and staffing) through ballot measures between 1960 and 1980.

Meanwhile, reflecting on the state-legislative research record, Jewell $(1969,148)$ wrote: "There is very little literature on the organization and structure of state legislatures." However, this was about to change. The small group of political scientists who studied state legislatures in the period beginning around 1970 was attracted to the subject by the institutional variation.

Although the reform period of the late 1960s and 1970 s was instrumental in overcoming the "institutional lag," not all states reformed in the same way or at the same rate. In effect, states were arrayed along a "capacity continuum," which became known as the degree of legislative professionalization (Squire 2017). Scholarly attention to the concept of legislative professionalization, or professionalism, is a defining characteristic of the postreform period (Hamm, Hedlund, and Miller 2014, 294-95). As Bowen and Greene (2014, 278) remarked, "The utility of legislative professionalism for the study of state politics is unquestionable."

For more than three decades, this concept has explained an array of differences between states and between state legislatures. Squire and Hamm (2005, 95-97) and Hamm, Hedlund, and Miller (2014, 303-307) identified at least eight subject areas in which state-legislative professionalization has an impact, including representational style, leadership style, electoral vulnerability, approach to agency oversight, and legislative output.

Using new techniques, recent research continues to illuminate the role of legislative professionalization. An especially interesting line of inquiry involves the relationship between the legislative capacity to process information and the willingness to adopt model legislation drafted by interest groups. a reaction to growing legislative professionalization and in part an effort to build momentum for congressional reform by using the direct-democracy process in the states, the termlimit movement became a widespread phenomenon. Beginning with the passage of term limits in 1990 in California, Colorado, and Oklahoma, the movement quickly spread to other states, becoming law in 21 states within a few years. All but one-Louisiana-are states with the initiative process. Eventually, term limits were invalidated in six states, leaving 15 states with term limits.

Occasionally, certain events provide clear opportunities for scholars to examine the behavioral effects of structural changes. For state scholars, three such opportunities involve changes in the electoral system. First is the reapportionment revolution (Ansolabehere and Snyder 2008). Second is the difference between representatives elected from singlemember districts compared to those from multi-member districts (Bertelli and Richardson 2008). Third, the term-limit movement of the 1990 s provided one of the most remarkable research opportunities ever presented to legislative scholars (Moncrief, Thompson, and Cassie 1996). Almost all of the states that adopted term limits did so within a six-year period; that, coupled with the clearly exogenous nature of the term-limit laws, made for a quasi-experiment research design attracting the interest of many political scientists.

In addition to numerous journal articles, term-limit research produced two rather unique research endeavors. One was the Joint Project on Term Limits, a cooperative study involving more than a dozen academics and staff members from three organizations representing state legislatures: the National Conference of State Legislatures, the Council of State Governments, and the National Legislative Leaders' Foundation. The project was a detailed comparative study of the effects across the term-limited states, and it resulted in a wide array of publications, including two books (Kurtz, Cain, 
and Niemi 2007; Farmer et al. 2006). It is an example of how academics and practitioners can work together on projects of mutual interest. The second project was the Michigan termlimit study, which involved almost two decades of intensive study of the effects of term limits in a specific state legislature. This project also led to several publications, including one book (Sarbaugh-Thompson and Thompson 2017). It is by far the most thorough study to date of the effect of term limits in a single state. such as legislatures. Second, data collection and dissemination were greatly facilitated by technological advances; this was especially true for state-level data. These changes conspired to change the trajectory of state-legislative research.

Space limitations do not allow a full accounting of the recent research now leveraging the variation in state-legislative structures and procedures to test theories first based on observations about the national legislature. However, there are a few examples of what is sure to continue as a fruitful line of study.

\section{The imposition of state-legislative term limits in the 1990s was the most significant institutional change in American legislatures since the capacity-building and reform efforts of the 1960 and 1970 (Kurtz, Cain, and Niemi 2007, 1).}

In his review of the literature, published a decade ago, Mooney (2009) identified more than 50 research studies on state-legislative term limits. Research is still being conducted and published on the topic today. Moreover, as Mooney had urged, the research has gone beyond examining the immediate effects of term limits per se; it now is more likely to treat term limits as simply one factor in testing a broader range of legislative theories. Recent research also is investigating the implications of term limits on specific policy areas. A particularly interesting example involves term limits, state budgets, and implications for fiscal-risk assessment (Forunato and Turner 2018; Keele, Malhotra, and McCubbins 2013; Lewis 2012).

\section{USING “THE N": RESEARCH ON INSTITUTIONAL RULES AND THEIR CONSEQUENCES}

Almost 40 years ago, Jewell (1981) wrote one of the first comprehensive reviews of the state of state-legislative research. His assessment was that research needed to be more theoretical and comparative, and he emphasized the need to bridge the gap between congressional and state-legislative research. Subsequent reviews (Clucas 2003; Moncrief, Thompson, and Cassie 1996) echoed that call.

State-legislative scholars long understood that one of their greatest research assets was "the N"-that is, the number of cases that state legislatures provided for analysis. However, this was largely a case of preaching to a rather small choir. The community of state-politics scholars was small. The majority of American political scientists focused on national political institutions, and the advantages of studying institutions at the state level did not resonate with them. The publication of 101 Chambers (Squire and Hamm 2005) was an important event in this regard. The specifically stated goal of their "primer" was to "help build bridges between the study of Congress and the study of state legislatures by identifying the points of comparison and contrast between the two sorts of institutions" (Squire and Hamm 2005, 3).

Two other trends that began a few years before the publication of 101 Chambers made this bridge more likely. First, shifts in the ever-evolving federal relationship in recent decades highlighted the visibility of the states and state institutions
One area involves the question of the role of committees in a legislature (Battista 2009). Another is how specific legislative rules constrain or facilitate the majority-party agenda (Anzia and Jackman 2013). A third area is using specific institutional rule changes as quasi-experimental investigations (Cox, Kousser, and McCubbins 2010).

State-legislative scholars always have been attracted to the institutional characteristics of their subjects-from institutional lag to institutional reform and professionalism; from the institutional shock of term limits to parsing out the effect of structures and procedural rules. Over time, more political scientists have discovered that attraction. Hamm, Hedlund, and Miller (2014, 294-96) provided a striking indication of this trend. They noted that fewer than 20 state-legislative research articles were published in refereed journals in the entire decade between 1965 and 1975-slightly fewer than two per year. Currently, about 20 such articles are published per year. That trend almost certainly will continue.

\section{RE F E RENCES}

Allen, Robert. 1949. Our Sovereign State. New York: Vanguard Press.

Ansolabehere, Stephen, and James M. Snyder, Jr. 2008. The End of Inequality: One Person, One Vote and the Transformation of American Politics. New York: W.W. Norton \& Co.

Anzia, Sarah, and Molly Jackman. 2013. "Legislative Organization and the Second Face of Power: Evidence from US State Legislatures." Journal of Politics 75 (1): 210-24.

Battista, James. 2009. "Why Information? Choosing Committee Informativeness in US State Legislatures.” Legislative Studies Quarterly. 34: 375-397.

Bertelli, Anthony, and Lillard E. Richardson. 2008. "Ideological Extremism and Electoral Design: Multi-Member versus Single-Member Districts." Public Choice 137: 347-68.

Bowen, Daniel, and Zachary Greene. 2014. "Should We Measure Legislative Professionalism with an Index? A Note on Theory and Practice in State Legislative Professionalism Research." State Politics and Policy Quarterly 14 (3): $277-96$.

Burns, John (ed.). 1971. The Sometimes Governments: An Evaluation of the Fifty American Legislatures. New York: Bantam Books.

Clucas, Richard. 2003. "Improving the Harvest of State Legislative Research." State Politics and Policy Quarterly 3: 387-419.

Cox, Gary, Thad Kousser, and Matthew McCubbins. 2010. "Party Power of Preferences? Quasi-Experimental Evidence from American State Legislatures." Journal of Politics 72 (3): 799-811. 
Farmer, Rick, Christopher Mooney, Richard Powell, and John Greene (eds.). 2006. Legislating without Experience: Case Studies in State Legislative Term Limits. Lanham, MD: Lexington Books.

Fortunato, David, and Ian Turner. 2018. "Legislative Capacity and Credit Risk." American Journal of Political Science 62 (3): 623-36.

Hamm, Keith; Ronald Hedlund, and Nancy Martorano Miller. 2014. "State Legislatures." In The Oxford Handbook of State and Local Government, ed. Donald Haider-Markel, 293-318 Oxford, UK: Oxford University Press.

Heard, Alexander. 1966. State Legislatures in American Politics. Englewood Cliffs, NJ: Prentice-Hall.

Hertel-Ferndandez, Alexander. 2014. "Who Passes Business's Model Bills? Policy Capacity and Corporate Influence in US State Politics." Perspectives on Politics 12 (3): 585-602.

Herzberg, Donald, and Alan Rosenthal (eds.). 1971. Strengthening the States: Essays on Legislative Reform. New York: Doubleday.

Jansa, Joshua, Eric Hansen, and Virginia Gray. 2018. "Copy and Paste Lawmaking: Legislative Professionalism and Policy Reinvention in the States." American Politics Research. Available at http://journals.sagepub.com/doi/1o. 1177/1532673X18776628.

Jewell, Malcolm. 1969. The State Legislature, second edition. New York: Random House.

Jewell, Malcolm. 1981. "Editor's Introduction: The State of US State Legislative Research." Legislative Studies Quarterly 6 (1): 1-25.

Keele, Luke, Neil Malhotra, and Colin McCubbins. 2013. "Do Term Limits Restrain Fiscal Policy? Approaches for Causal Inference in Assessing the Effect of Legislative Institutions." Legislative Studies Quarterly 38 (3): 291-326.

Kurtz, Karl T. 2010. "75 Years of Institutional Change in State Legislatures." Book of the States, 2010 ed. Lexington, KY: Council of State Governments.
Kurtz, Karl, Bruce Cain, and Richard Niemi (eds.). 2007. Institutional Change in American Politics: The Case of Term Limits. Ann Arbor: University of Michigan Press.

Lewis, Daniel C. 2012. "Legislative Term Limits and Fiscal Policy Performance." Legislative Studies Quarterly 37: 305-328.

Miller, James Nathan. 1965. "Hamstrung Legislatures.” National Civic Review. 54: 178-219.

Moncrief, Gary, Joel Thompson, and William Cassie. 1996. "Revisiting the State of US State Legislative Research." Legislative Studies Quarterly 21 (3): 301-35.

Mooney, Christopher. 2009. "Term Limits as a Boon to Legislative Scholarship: A Review." State Politics and Policy Quarterly 9 (2): 204-28.

Rosenthal, Alan. 1998. The Decline of Representative Democracy. Washington, DC: CQ Quarterly.

Sanford, Terry. 1967. Storm Over the States. New York: McGraw-Hill.

Sarbaugh-Thompson, Marjorie, and Lyke Thompson. 2017. Implementing Term Limits: The Case of the Michigan Legislature. Ann Arbor: University of Michigan Press.

Squire, Peverill. 2012. The Evolution of American Legislatures: Colonies, Territories and States, 1619-2009. Ann Arbor: University of Michigan Press.

Squire, Peverill. 2017. “A Squire Index Update.” State Politics and Policy Quarterly 17 (3): 361-71.

Squire, Peverill, and Keith Hamm. 2005. 101 Chambers: Congress, State Legislatures and the Future of Legislative Studies. Columbus: The Ohio State University Press.

Wiltsee, Herbert. 1966. "Legislative Organization and Services." The Book of the States, 1966-67. Chicago: Council of State Governments.

Zeller, Belle (ed.). 1954. American State Legislatures. New York: Thomas Crowell. 